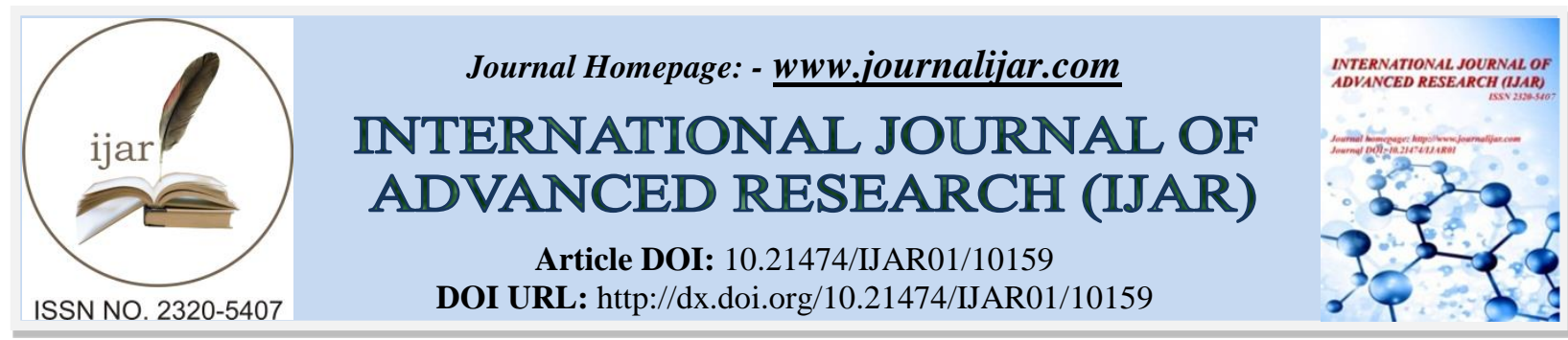

RESEARCH ARTICLE

\title{
INFLUENCE OF SALT CONTENT IN MINERALIZED WATERS ON THE EXPENDITURE OF OXIDIZERS WHEN PRODUCING IODINE FROM UNDERGROUND SALT WATERS.
}

\author{
Umbarov I.A., Turaev H.Kh., Xamzaev N.J. and Eshonqulov H.N.
}

Termez State University, Termez, Uzbekistan.

\section{Manuscript Info}

\section{Manuscript History}

Received: 03 October 2019

Final Accepted: 05 November 2019

Published: December 2019

Key words:-

Iodine, Bromine, Oxidizing Agent, Iodine-Containing Water, Deposits, Salt

Water, Mineralization

\begin{abstract}
Studies the effect of salt content in mineralized waters on the consumption of oxidizing agents in the production of iodine from underground salt water. Surkhandarya region, in particular, the Kattakum-2 well of the Khudag field, Uchkyzyl, Kokaity and Urtabulok of the Bukhara-Karshi depression. It was revealed that with an increase in the salinity of underground hydrothermal waters of the studied deposits from $113 \mathrm{~g} / 1$ to $283 \mathrm{~g} / 1$, the flow rate of the amount of the solution of oxidizing agents and sulfuric acid increases proportionally.
\end{abstract}

Copy Right, IJAR, 2019,. All rights reserved.

\section{Introduction:-}

Natural deposits containing iodine, bromine and other valuable components are objects for their industrial production. The latter include natural water (thermal), drilling water (associated oil), sea water and ocean water, as well as saltpeter deposits (Chile, Peru). A number of industrial iodine-containing groundwater has been discovered on the territory of our republic, located mainly in the Ferghana, Bukhara-Karshi and Surkhandarya artesian basins and on the Ustyurt plateau [1].

Experimental part. The object of this research work is the thermal waters of the Surkhandarya region, in particular, the Kattakum-2 well of the Khudag field, Uchkyzyl, Kokait and Urtabulok of the Bukhara-Karshi Depression. The data obtained are shown in table 1.

Table 1:- The chemical composition of groundwater samples of Surkhandarya and Urtabulok of the Bukhara-Karshi depression.

\begin{tabular}{|c|c|c|c|c|c|c|c|c|c|c|c|c|c|}
\hline \multirow[b]{2}{*}{$\begin{array}{c}\text { Min- } \\
\mathrm{n} \\
\mathrm{mg} / \\
\mathrm{L}\end{array}$} & \multirow[t]{2}{*}{$\mathrm{pH}$} & \multirow{2}{*}{$\begin{array}{l}\mathrm{T},{ }^{\circ} \\
\mathrm{C}\end{array}$} & \multirow{2}{*}{$\begin{array}{c}\text { Operatio } \\
\text { n } \\
\text { reserves, } \\
\mathrm{m}^{3} / \text { day. }\end{array}$} & \multicolumn{10}{|c|}{ Content, $\mathrm{mg} / \mathrm{L}$} \\
\hline & & & & $\mathrm{I}_{2}$ & $\mathrm{Br}_{2}$ & $\mathrm{NaCl}$ & $\mathrm{KCl}$ & $\begin{array}{c}\mathrm{LiC} \\
1\end{array}$ & $\mathrm{CaCl}_{2}$ & $\begin{array}{c}\mathrm{MgCl} \\
2\end{array}$ & $\begin{array}{c}\mathrm{SrCl} \\
2\end{array}$ & $\mathrm{FCl}_{2}$ & $\mathrm{H}_{2} \mathrm{O}$ \\
\hline \multicolumn{14}{|c|}{ Khaudag Kattakum- 2 underground salt water deposits } \\
\hline $\begin{array}{c}210, \\
0\end{array}$ & $\begin{array}{l}6, \\
3\end{array}$ & $\begin{array}{c}72 \\
76 \\
\end{array}$ & 414,8 & $\begin{array}{c}21,3 \\
2\end{array}$ & $\begin{array}{c}426 \\
4\end{array}$ & $\begin{array}{c}14280 \\
0\end{array}$ & $\begin{array}{c}420 \\
0\end{array}$ & 420 & $\begin{array}{c}4830 \\
0\end{array}$ & 10940 & 1240 & $\begin{array}{c}210 \\
0\end{array}$ & $\begin{array}{c}79000 \\
0\end{array}$ \\
\hline \multicolumn{14}{|c|}{ Deposits of underground salt waters Uchkizil } \\
\hline $\begin{array}{c}283, \\
0\end{array}$ & $\begin{array}{l}5, \\
1\end{array}$ & 40 & 216,3 & 20,7 & $\begin{array}{c}391, \\
4\end{array}$ & $\begin{array}{c}18678 \\
0\end{array}$ & $\begin{array}{c}283 \\
0\end{array}$ & - & $\begin{array}{c}7358 \\
0\end{array}$ & 16980 & 710 & $\begin{array}{c}212 \\
0\end{array}$ & $\begin{array}{c}71700 \\
0\end{array}$ \\
\hline
\end{tabular}

Corresponding Author:- Umbarov I.A.

Address:- Termez State University, Termez, Uzbekistan. 


\begin{tabular}{|c|c|c|c|c|c|c|c|c|c|c|c|c|c|}
\hline \multicolumn{14}{|c|}{ Deposits of underground salt waters Kakaydi } \\
\hline $\begin{array}{c}142, \\
9\end{array}$ & $\begin{array}{l}6, \\
7\end{array}$ & 39 & 785,4 & 17,4 & $\begin{array}{c}313, \\
2\end{array}$ & $\begin{array}{c}10003 \\
0\end{array}$ & $\begin{array}{c}214 \\
0\end{array}$ & 240 & $\begin{array}{c}2715 \\
0\end{array}$ & 10290 & 630 & $\begin{array}{c}243 \\
0\end{array}$ & $\begin{array}{c}85600 \\
0\end{array}$ \\
\hline \multicolumn{14}{|c|}{ Deposits of underground salt waters swimming-pool of Bukhara-Karshi } \\
\hline $\begin{array}{c}113, \\
0\end{array}$ & $\begin{array}{l}6, \\
8\end{array}$ & 45 & 9873 & $\begin{array}{c}24,4 \\
3\end{array}$ & 376 & 80230 & $\begin{array}{c}339 \\
0\end{array}$ & 320 & $\begin{array}{c}2373 \\
0\end{array}$ & 3910 & 330 & $\begin{array}{c}110 \\
0\end{array}$ & $\begin{array}{c}88700 \\
0\end{array}$ \\
\hline
\end{tabular}

\section{Results and its Discussion:-}

The table shows that the iodine content in the waters of the Surkhandarya basin ranges from 17.4-24.34 mg / 1, and bromine $313.2-426.4 \mathrm{mg} / \mathrm{l}$, at a $\mathrm{pH}$ of 5.1-6.7, and a temperature of $39-76^{\circ} \mathrm{C}$, and mineralization $142.9-283.0 \mathrm{~g} / 1$ depending on the field. Based on the results of our studies (Table 1), we came to the conclusion that the most promising for the extraction of iodine are the Urtabulak and Khaudag (Kattakum-2) deposits.

The relationship between the consumption of oxidizing agents and the amount of salts during the separation of iodine from mineralized waters for the deposits of Urtabulak, Kokaity, Khaudag and Uchkyzyl was also studied. For the complete oxidation of iodine compounds from iodine-containing test waters, the required amount of a solution of oxidizing agents and sulfuric acid depends on the salinity of the water. The results of experimental studies are shown in table 2.

Table 2:- The relationship between the consumption of oxidizing agents and the amount of salts in mineralized waters during the release of iodine $(\mathrm{V}=50 \mathrm{ml})$

\begin{tabular}{|c|c|c|c|c|c|c|c|}
\hline \multirow[t]{2}{*}{ № } & \multirow{2}{*}{$\begin{array}{l}\text { Name of } \\
\text { field }\end{array}$} & \multirow{2}{*}{$\begin{array}{l}\text { Min-tion of } \\
\text { water, } g \text { / }\end{array}$} & \multirow{2}{*}{$\begin{array}{c}\text { Volume } \\
2 \% \mathrm{H}_{2} \mathrm{SO}_{4} \\
\mathrm{ml} .\end{array}$} & \multicolumn{4}{|c|}{ The amount of oxidizing agents, $\mathrm{ml}$} \\
\hline & & & & $\begin{array}{c}2 \% \\
\mathrm{Na}_{2} \mathrm{~S}_{2} \mathrm{O}_{8}\end{array}$ & $\begin{array}{c}2 \% \\
\mathrm{Ca}(\mathrm{CIO})_{2}\end{array}$ & $\begin{array}{c}2 \% \\
\mathrm{NaNO}_{2}\end{array}$ & $\begin{array}{c}5 \% \\
\mathrm{H}_{2} \mathrm{O}_{2} \\
\end{array}$ \\
\hline 1 & Urtabulak & 113 & 0,132 & 0,20 & 0,154 & 0,120 & 0,074 \\
\hline 2 & Kakaydi & 142 & 0,166 & 0,29 & 0,225 & 0,175 & 0,124 \\
\hline 3 & Khaudag & 210 & 0,245 & 0,37 & 0,287 & 0,223 & 0,138 \\
\hline 4 & Uchkizil & 283 & 0,330 & 0,55 & 0,450 & 0,350 & 0,225 \\
\hline
\end{tabular}

According to the data obtained, the mineralization of the Urtabulak deposit is $113 \mathrm{~g} / 1$ and $0.132 \mathrm{ml}$ of $2 \%$ sulfuric acid is consumed to acidify $50 \mathrm{ml}$ of the studied waters. Also, the consumption of solutions of the used oxidizing agents is associated with the consumption of sulfuric acid in stoichiometric ratios, respectively, as follows: $2 \%$

Fig. 1:- The effect of salt content in mineralized waters on the consumption of oxidizing agents in the production of iodine: $1-2 \%$ Na2S2O $;$; $2-2 \% \mathrm{Ca}(\mathrm{CIO}) 2 ; 3-2 \% \mathrm{NaNO} 2 ; 4-5 \% \mathrm{H} 2 \mathrm{O} 2$

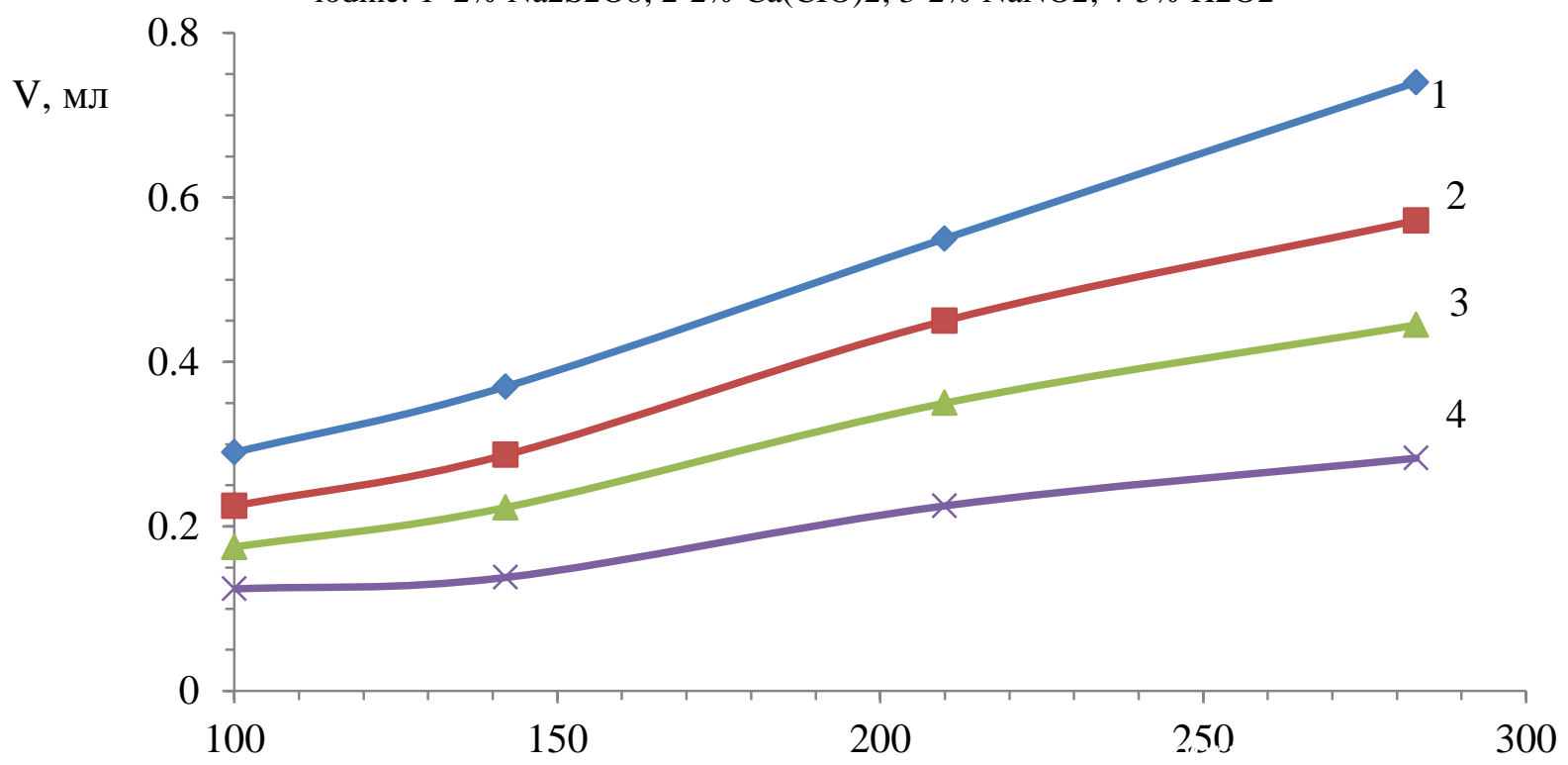




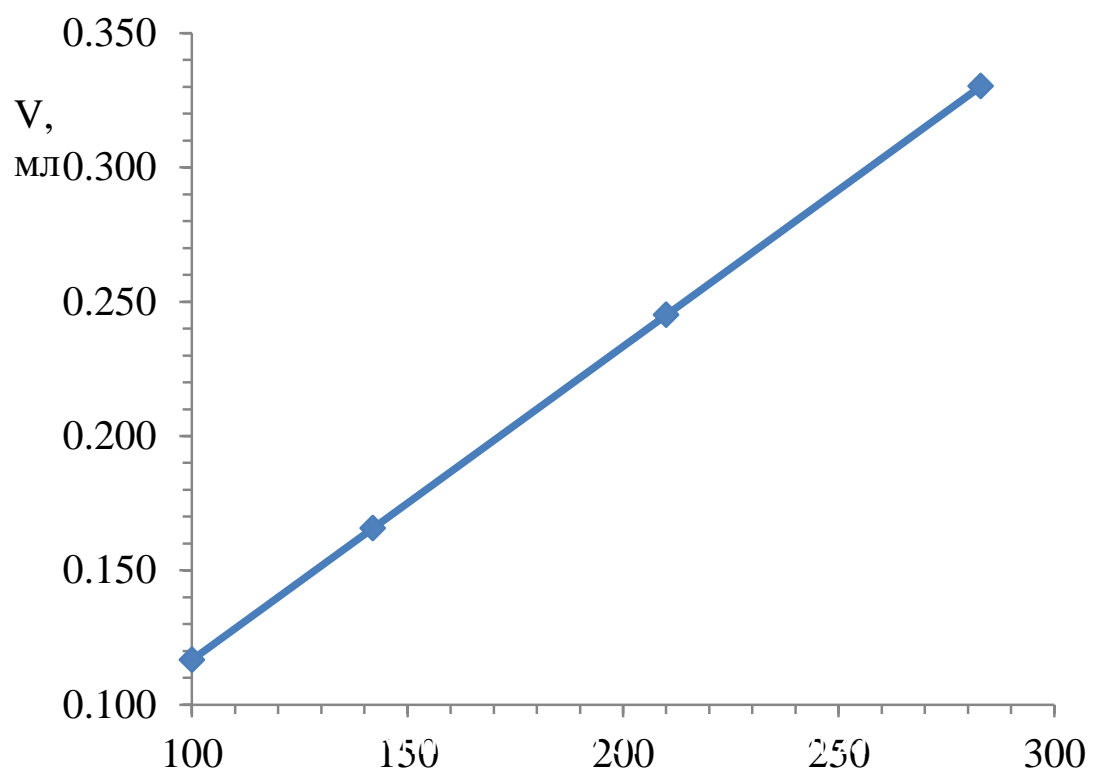

Fig. 2:- The effect of salt content in mineralized waters on the consumption of $2 \%$ sulfuric acid in the production of iodine $\mathrm{Na} 2 \mathrm{~S} 2 \mathrm{O} 8-0.20 \mathrm{ml} ; 2 \% \mathrm{Ca}(\mathrm{C} 1 \mathrm{O}) 2-0.154 \mathrm{ml} ; 2 \% \mathrm{NaNO} 2-0.120 \mathrm{ml} ; 5 \% \mathrm{H} 2 \mathrm{O} 2-0.074 \mathrm{ml}$.

The mineralization of the Kokait deposit is $142 \mathrm{~g} / 1$, and $0.166 \mathrm{ml}$ of $2 \%$ sulfuric acid is consumed to acidify $50 \mathrm{ml}$ of the test water. Also, the consumption of solutions of the used oxidizing agents is associated with the consumption of sulfuric acid in stoichiometric ratios, respectively, as follows: $2 \% \mathrm{Na} 2 \mathrm{~S} 2 \mathrm{O} 8-0.29 \mathrm{ml} ; 2 \% \mathrm{Ca}(\mathrm{C} 1 \mathrm{O}) 2-0.225 \mathrm{ml}$; $2 \% \mathrm{NaNO} 2-0.175 \mathrm{ml} ; 5 \% \mathrm{H} 2 \mathrm{O} 2-0.124 \mathrm{ml}$.

The mineralization of the Khaudag deposit is $210 \mathrm{~g} / 1$, and $0.245 \mathrm{ml}$ of $2 \%$ sulfuric acid is consumed to acidify 50 $\mathrm{ml}$ of the studied water. Also, the consumption of solutions of the used oxidizing agents is associated with the consumption of sulfuric acid in stoichiometric ratios as follows: $2 \% \mathrm{Na} 2 \mathrm{~S} 2 \mathrm{O} 8-0.370 \mathrm{ml} ; 2 \% \mathrm{Ca}(\mathrm{C} 1 \mathrm{O}) 2-0.287 \mathrm{ml}$; $2 \% \mathrm{NaNO} 2-0.223 \mathrm{ml} ; 5 \% \mathrm{H} 2 \mathrm{O} 2-0.138 \mathrm{ml}$.

The mineralization of the Uchkyzyl deposit is $283 \mathrm{~g} / 1$, and $0.330 \mathrm{ml}$ of $2 \%$ sulfuric acid is consumed to acidify 50 $\mathrm{ml}$ of the studied waters. Also, the consumption of solutions of the used oxidizing agents is associated with the consumption of sulfuric acid in stoichiometric ratios, respectively, as follows: $2 \% \mathrm{Na} 2 \mathrm{~S} 2 \mathrm{O} 8-0.550 \mathrm{ml} ; 2 \%$ $\mathrm{Ca}(\mathrm{C} 1 \mathrm{O}) 2$ - $0.450 \mathrm{ml} ; 2 \% \mathrm{NaNO} 2-0.350 \mathrm{ml} ; 5 \% \mathrm{H} 2 \mathrm{O} 2$ - $0.225 \mathrm{ml}$.

Thus, it was found that with an increase in the salinity of underground hydrothermal waters of the studied deposits from $113 \mathrm{~g} / 1$ to $283 \mathrm{~g} / 1$, the flow rate of the amount of a solution of oxidizing agents and sulfuric acid increases proportionally.

\section{Conclusions:-}

1. Based on the results of our studies (Table 1), we came to the conclusion that the most promising for the extraction of iodine are the Urtabulak and Khaudag (Kattakum-2) deposits.

2. It has been proved that the increase in the salinity of underground hydrothermal waters in the Kattakum-2, Uchkizyl, Kokait and Urtabulak deposits when iodine is separated from iodine-containing compounds from 113 $\mathrm{g} / 1$ to $283 \mathrm{~g} / 1$ is proportional to the flow rate of the solution of oxidizing agents and sulfuric acid, that is, the consumption of oxidizing agents increases by 2.5 times, and sulfuric acid by 1.5 times.

\section{Reference:-}

1. Umbarov I.A., Turaev H.Kh. Determination of the elemental composition of groundwater salt water // Science Time. -Kazan. - 2018. - No. 2 S.- 76-80. 